\title{
Genomic alterations of primary tumor and blood in invasive ductal carcinoma of breast
}

\author{
Ja Seong Bae', Jin Soo Choi ${ }^{2}$, Seung Ho Baik², Woo Chan Park', Byung Joo Song ${ }^{1}$, Jeong Soo Kim', Young Lim³, \\ Sang Seol Jung ${ }^{1 *}$
}

\begin{abstract}
Background: Genomic alterations are important events in the origin and progression of various cancers, with DNA copy number changes associated with progression and treatment response in cancer. Array CGH is potentially useful in the identification of genomic alterations from primary tumor and blood in breast cancer patients. The aim of our study was to compare differences of DNA copy number changes in blood and tumor tissue in breast cancer.

Methods: DNA copy number changes in blood were compared to those in tumor tissue using array-comparative genomic hybridization in samples obtained from 30 breast cancer patients. The relative degree of chromosomal changes was analyzed using log2 ratios and data was validated by real-time polymerase chain reaction.

Results: Forty-six regions of gains present in more than $30 \%$ of the tissues and 70 regions of gains present in more than $30 \%$ of blood were identified. The most frequently gained region was chromosome $8 q 24$. In total, agreement of DNA copy numbers between primary tumor and blood was minimal (Kappa $=0.138, p<0.001$ ).
\end{abstract}

Conclusion: Although there was only a slight agreement of DNA copy number alterations between the primary tumor and the blood samples, the blood cell copy number variation may have some clinical significance as compared to the primary tumor in IDC breast cancer patients.

\section{Background}

Breast cancer is the most frequently occurring malignancy in Korean women [1]. Even with advances in diagnosis and treatment of breast cancer, the prognosis and survival of patients with breast cancer remains unsatisfactory. Histological and molecular heterogeneity of breast cancer, even in the same stage, hampers the use of standardized treatment. Many women might benefit from more aggressive therapy while others unnecessarily receive treatment. With the aim of individualizing therapy and to refine predictive prognosis, studies have sought to identify biomolecular markers and candidate genes [2-6]. Thus, it is crucial to elucidate the mechanisms involved in breast cancer carcinogenesis at the genetic and molecular levels.

Genomic instability including gain or loss of the region-specific genomic DNA copy number is associated with cancer development and progression [7]. These

\footnotetext{
* Correspondence: ssjung@catholic.ac.kr

'Department of Surgery, The Catholic University, Seoul, Korea
}

DNA copy number alterations may result in overexpression of oncogenes with DNA amplification or deletion of tumor suppressor genes [8]. Analysis of DNA copy number changes have been performed using karyotyping, fluorescence in situ hybridization (FISH), comparative genomic hybridization $(\mathrm{CGH})$, and loss of heterozygosity $(\mathrm{LOH})$. However, these methods are limited by their resolution and inability to assess genetic information.

Array-comparative CGH (array-CGH) has been performed to localize DNA copy number changes associated with various human cancers [9-12] and to compare the abundance of specific genomic sequences in whole-tumor DNA relative to normal reference genomes. Array $\mathrm{CGH}$ can provide high resolution and dynamic range with more accurate mapping of regions [13-15], and has been used successfully as a tool for the identification of aberrations in breast cancer $[16,17]$.

Array CGH utilizes fresh frozen or formalin-fixed, paraffin-embedded tissue (FFPE) to detect chromosomal alterations in tumor DNA. Although FFPE has been 
widely used to archive samples obtained from various human cancer, characterization is mainly limited to cytogenetic techniques that analyze genetic changes at the chromosomal level $[18,19]$. On the other hand, fresh frozen tissues provide the highest quality nucleic acid for analysis. But, clinical availability is often limited. A possible alternative is whole blood samples, since array CGH using whole blood samples has been used for diagnostic testing of patients with mental retardation, birth defects, and behavioral problems [20].

The aim of our study was to compare the chromosomal abnormalities in DNA between fresh frozen tissue and peripheral blood to determine if peripheral blood rather than fresh frozen tissue can be applied for clinical assessment in breast cancer patients.

\section{Methods}

\section{Sample acquisition}

Fresh tissue and peripheral blood samples were each obtained from 30 patients with histologically confirmed breast cancer at the Department of General Surgery at Kangnam St. Mary's Hospital, the Catholic University of Korea following their informed consent. The clinicopathological characteristics of the samples are shown in Table 1. gDNA was extracted from a frozen fragment of the tumor tissue, using a micro-dissection technique to reduce contamination with non-neoplastic tissue. Each tissue sample was incubated overnight at $55^{\circ} \mathrm{C}$ with cell lysis buffer and $10 \mu \mathrm{l}$ proteinase $\mathrm{K}(>600 \mathrm{mAU} / \mathrm{ml})$ (Qiagen, Germany). PBMC was obtained by fycoll hypaque density gradient. Whole genomic DNA was extracted using a Puregene DNA isolation kits (Gentra Systems, USA). The reference sample was used from commercial DNA source (Promega, USA).

\section{Array CGH analysis}

The array used in this study consisted of 4,030 bacterial artificial chromosome (BAC) clones representing duplicates of regions of the whole human genome yielding a resolution of about $1 \mathrm{Mbp}$. DNA was labeled using the Bioprime labeling kit (Invitrogen, USA). Genomic DNA samples (500 700 ng) with random primers were boiled at $98-100^{\circ} \mathrm{C}$ for $5 \mathrm{~min}$ for denaturation and then cooled on ice for $5 \mathrm{~min}$. The denatured DNA was differentially labeled with $3 \mu \mathrm{l}$ of $1 \mathrm{mM}$ Cy 3 and Cy 5 conjugated dCTP (Perkin-Elmer, USA) by random primer labeling, and $1 \mu \mathrm{l}$ Klenow fragments were added to the mixture. DNA was incubated at $37^{\circ} \mathrm{C}$ overnight. After labeling, unincorporated nucleotides were removed using MicroSpin G-50 columns (Amersham Biosciences, England). Cy3 and Cy5 labeled test DNA and reference DNA were mixed with $50 \mu \mathrm{g}$ of human Cot-1 DNA to block repeat sequences. After purification, the mixture was resolved in hybridization buffer containing yeast tRNA to block
Table 1 Demographics of patients and tumor characteristics

\begin{tabular}{|c|c|}
\hline Characteristic & No. of patients $(n=30)$ \\
\hline Mean age (years) \pm SD (range) & $49.2 \pm 8.6(35-70)$ \\
\hline \multicolumn{2}{|l|}{ Histological subtype } \\
\hline Invasive ductal carcinoma & 30 \\
\hline \multicolumn{2}{|l|}{ Tumor status } \\
\hline $\mathrm{T} 1$ & 15 \\
\hline $\mathrm{T} 2$ & 13 \\
\hline T3 & 2 \\
\hline \multicolumn{2}{|l|}{ Lymph node status } \\
\hline NO & 17 \\
\hline N1 & 7 \\
\hline $\mathrm{N} 2$ & 4 \\
\hline N3 & 2 \\
\hline \multicolumn{2}{|l|}{ TNM stage } \\
\hline I & 15 \\
\hline$\|$ & 9 \\
\hline III & 6 \\
\hline \multicolumn{2}{|l|}{ Tumor differentiation } \\
\hline Well & 4 \\
\hline Moderate & 18 \\
\hline Poor & 8 \\
\hline \multicolumn{2}{|l|}{ Hormone receptor status } \\
\hline \multicolumn{2}{|l|}{ Estrogen receptor } \\
\hline Positive & 21 \\
\hline Negative & 9 \\
\hline \multicolumn{2}{|l|}{ Progesterone receptor } \\
\hline Positive & 13 \\
\hline Negative & 17 \\
\hline \multicolumn{2}{|l|}{ HER-2 receptor status } \\
\hline Positive & 9 \\
\hline Negative & 21 \\
\hline
\end{tabular}

binding of non-specific nucleotides. MACArray ${ }^{\mathrm{TM}}$-Karyo 4 K BAC-chips (Macrogen, Korea) were prehybridized in hybridization buffer with salmon sperm DNA for 30 min prior to hybridization with the purification mixture and incubated for $72 \mathrm{~h}$ in a $37^{\circ} \mathrm{C}$ hybridization chamber. After hybridization was complete, array chips were washed in $50 \%$ formamide- $2 \times \mathrm{SSC}$ at $46^{\circ} \mathrm{C}$ for 15 min, and then $0.1 \%$ sodium dodecyl sulfate- $2 \times$ sodium chloride-sodium citrate (SSC) buffer at $46^{\circ} \mathrm{C}$ for $30 \mathrm{~min}$. In the next step, the chips were washed in $50 \%$ sodium phosphate $0.1 \%$ NP40 for 15 min followed by washing in $2 \times \mathrm{SSC}$ buffer for $5 \mathrm{~min}$ at room temperature. After spin drying, hybridized arrays were scanned with a MAC Viewer2 ${ }^{\mathrm{TM}}$ (Macrogen).

\section{Data analyses}

The scanned images were analyzed using MAC viewer v.2 Software (Macrogen) to determine the Cy3:Cy5 ratio for each array element. Data were depicted as $\log _{2}$ (Cy3 
intensity/Cy5 intensity ratios) plotted against the position of clones within the particular chromosome as per the current version of the genome. Based on the ratios of clones mapping to chromosome $\mathrm{X}$ in a hybridization of normal female DNA, a specific amplicon was determined (Fig. 1). A ratio of 1.0 indicated a balanced stage of DNA with respect to gain and loss between tissue or blood samples and reference samples; the $\log _{2}$ ratio value was plotted as the zero value. A threshold level for determining significant DNA loss was defined as $\log _{2}$ ratio $<-0.5$, while $\log _{2}$ ratio $>0.5$ represented significant gains. The threshold corresponded to two standard deviations (SD). Centromere regions were excluded from the analysis, which averaged $10 \mathrm{Mb}$ in all chromosomes. The information on each individual clone was obtained from the University of California at Santa Cruz (UCSC) Genome Bioinformatics database http://genome.ucsc.edu.

\section{Real time-quantitative polymerase chain reaction (PCR)}

To confirm genomic imbalances identified by array CGH, DNA samples with obvious genomic changes were analyzed using real time PCR. Primers for clones were selected and the position of each clone was obtained from the UCSC genome database. For relative quantification, the reactions were performed in a total volume of $25 \mu \mathrm{l}$ that included $12.5 \mu \mathrm{l}$ of $2 \times \mathrm{IQ}^{\mathrm{TM}} \mathrm{SYBR}$ Green ${ }^{\circ}$ Supermix (Bio-Rad, USA), $1 \mu \mathrm{l}$ of DNA (10 $\mathrm{ng} / \mu \mathrm{l})$, and $1 \mu \mathrm{l}$ of each primer $(10 \mathrm{pmol} / \mu \mathrm{l})$. The PCR amplification and detection steps were carried out in an iCycler (BioRad) with $30 \mathrm{~s}$ at $95^{\circ} \mathrm{C}, 60^{\circ} \mathrm{C}$, and $72^{\circ} \mathrm{C}$ for 30 cycles after the initial $5 \mathrm{~min}$ denaturation step at $94^{\circ} \mathrm{C}$. The threshold cycle $\left(\mathrm{C}_{\mathrm{T}}\right)$ value was calculated using the comparative $C_{T}$ method (Poropat et al. 1998). $C_{T}$ for each gene was determined using thermocycler software and an average of three independent experiments was calculated. The $\mathrm{N}$-value of the target gene was normalized to an endogenous reference, glyceraldehyde 3-phosphate dehydrogenase, which shows no significant changes in each genome [21,22].

\section{Results}

Initially, we reviewed the existing literature on oncogenes associated with human breast cancer in breast cancer tissues and compared our results (Table 2). For example, chromosome 8 alterations including a gain of $8 \mathrm{q} 24$ are commonly observed in breast cancer $[23,24]$. The MYC oncogene in the $8 \mathrm{q} 24$ region is associated with a worsened prognosis or more aggressive clinical features [25]. This region was amplified in $90 \%$ of the presently studied tumors.

We identified 46 regions of gain present in more than $30 \%$ of the primary tumor samples and 70 regions of gain present in more than $30 \%$ of blood samples. The most frequently gained region was chromosome $8 \mathrm{q} 24$. This region was present in $20 / 30(67 \%)$ of the tumor samples and $23 / 30(77 \%)$ of the blood samples. The frequency of copy number loss was lower than that of copy number gains. There were 11 regions of loss found in more than $13 \%$ of the primary tumors and 16 regions of loss found in more than $13 \%$ of blood (Tables 3 and 4 ).

Thirty other regions of copy number gain were detected in at least $30 \%$ of both primary tumors and blood (Table 5). Among these, seven regions of copy number gain were found in more than $50 \%$ of both primary tumors and blood. A gain of 5 p15.33 was evident in $24 / 30(80 \%)$ of the primary tumors and $17 / 30(57 \%)$ blood samples. The region on $5 \mathrm{p} 15.33$ was found to contain AHRR, EXOC3 and SLC9A3. A gain at 8q24.3 was frequently detected. This region was found to contain HSF1, DGAT1, SCRT1, FBXL6, GPR172A and ADCK5. A gain of 17q11.2 was evident in 19/30 (63\%) of the primary tumors and $17 / 30(57 \%)$ of the blood samples. The region on $17 \mathrm{q} 11.2$ was found to contain MYO18A. A gain of 20q13.33 was detected in 16/30 (53\%) of the primary tumors and $19 / 30$ (63\%) of the blood samples. This region was found to contain LAMA5, RPS21, CABLES2 and C20orf151. Gain of 22 q 13.33 was detected in $50 \%$ of both primary tumors and blood. This region on 22q13.33 was found to contain MOV10L1, PANX2, TUBGCP6, HDAC10, MAPK12, MAPK11, and PLXNB2.

Genomic losses of blood were most often present in $2 \mathrm{q}(23 \%), 10 \mathrm{q}(27 \%), 14 \mathrm{q}(27 \%), 18 \mathrm{p}(27 \%)$ and $22 \mathrm{q}$ (47\%). Chiefly tumor observed aberration of DNA loss regions in $14 \mathrm{q}(27 \%), 17 \mathrm{p}(40 \%)$ and $22 \mathrm{q}(37 \%)$. Only one region of copy number loss was detected in more than $30 \%$ of both primary tumors and blood. This region comprised chromosome $22 \mathrm{q} 11.21$, and was detected in $11 / 30$ (37\%) of primary tumors and $14 / 30$ (47\%) of blood. The region on 22q11.21 was found to contain GGT2.

To confirm the array CGH results, DNA copy numbers between primary tumor and blood samples were evaluated by real time PCR. As for the array $\mathrm{CGH}$ results, several frequently altered loci were found. We selected four related genes that might represent putative candidate genes involved in breast cancer (Fig. 2). Primers for the three genes are presented in Table 6. The clone positions were retrieved from the UCSC genome database (Table 6).

In the comparison of the results of array $\mathrm{CGH}$ with those of real time PCR, the array $\mathrm{CGH}$ values were represented by linear-ratios and the $\mathrm{N}$-value was delineated by real time PCR (Fig. 2). The relative fold increases by real time PCR of three genes were consistent with those obtained from array $\mathrm{CGH}$. A parallel examination demonstrated that the gene copy number 


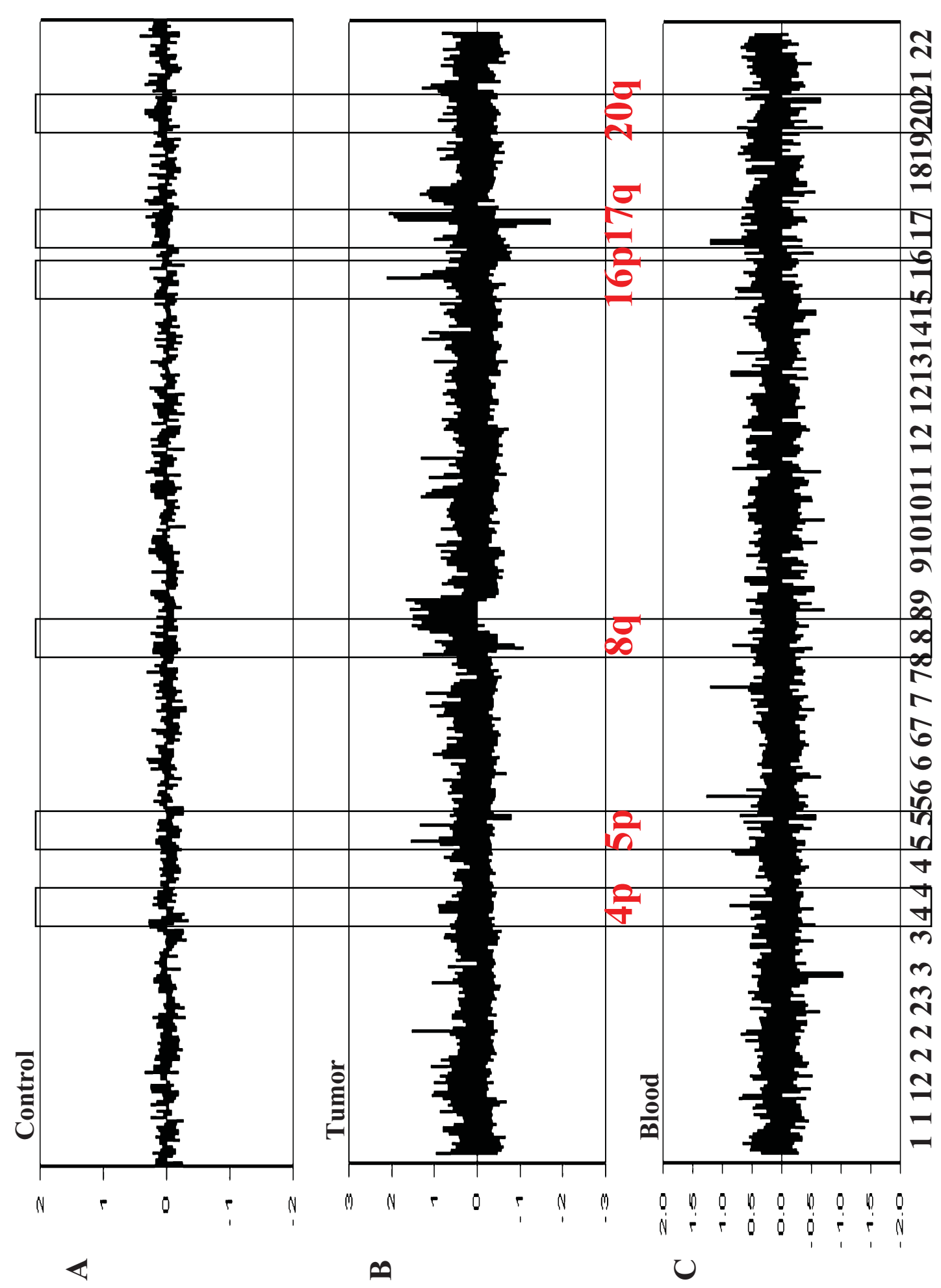

Figure 1 DNA copy number changes in a representative 30 IDC of each blood and tumor tissue. Results of array CGH analysis of 30 IDC human breast cancer tumor tissues and blood. The copy number fold change is shown on the $y$-axis and the genomic location is shown on the $\mathrm{X}$-axis of panels $\mathrm{A}$ and $\mathrm{B}$. 
Table 2 Recurrent gains in breast cancer tissues with examples of some candidate oncogenes

\begin{tabular}{|c|c|c|c|c|c|}
\hline specimens & Chr. & $\begin{array}{l}\text { BAC_Start } \\
\text { (bp) }\end{array}$ & $\begin{array}{l}\text { BAC_End } \\
\text { (bp) }\end{array}$ & $\begin{array}{l}\text { Size } \\
(\mathrm{bp})\end{array}$ & $\begin{array}{l}\text { Cancer } \\
\text { Genes }\end{array}$ \\
\hline $\mathrm{BC}-1 ; \mathrm{BC}-2 ; \mathrm{BC}-5 ; \mathrm{BC}-8 ; \mathrm{BC}-14 ; \mathrm{BC}-17 ; \mathrm{BC}-18 ; \mathrm{BC}-19$ & 1 & 58958809 & 59044901 & 86092 & JUN \\
\hline \multirow{2}{*}{$\begin{array}{l}\mathrm{BC}-1 ; \mathrm{BC}-2 ; \mathrm{BC}-3 ; \mathrm{BC}-4 ; \mathrm{BC}-5 ; \mathrm{BC}-6 ; \mathrm{BC}-7 ; \mathrm{BC}-8 ; \mathrm{BC}-9 ; \mathrm{BC}-10 ; \mathrm{BC}-11 ; \mathrm{BC}-13 ; \mathrm{BC}-14 ; \mathrm{BC}-17 ; \mathrm{BC}-18 ; \mathrm{BC}-19 ; \mathrm{BC}-20 \\
\mathrm{BC}-21 ; \mathrm{BC}-22 ; \mathrm{BC}-23 ; \mathrm{BC}-25 ; \mathrm{BC}-26 ; \mathrm{BC}-28 ; \mathrm{BC}-30\end{array}$} & 8 & 128800101 & 128877465 & 77364 & MYC \\
\hline & 8 & 134244673 & 134344801 & 100128 & WISP1 \\
\hline $\mathrm{BC}-1 ; \mathrm{BC}-2 ; \mathrm{BC}-5 ; \mathrm{BC}-7 ; \mathrm{BC}-8 ; \mathrm{BC} 9 ; \mathrm{BC}-10 ; \mathrm{BC}-17 ; \mathrm{BC}-21 ; \mathrm{BC}-23 ; \mathrm{BC}-25 ; \mathrm{BC}-26 ; \mathrm{BC}-29 ; \mathrm{BC}-30$ & 10 & 103483027 & 103545553 & 62526 & FGF8 \\
\hline$B C-14 ; B C-16 ; B C-17 ; B C-26 ; B C-30$ & 11 & 499204 & 651925 & 152721 & HRAS \\
\hline$B C-22 ; B C-26 ; B C-28$ & 11 & 69236764 & 69325605 & 88841 & FGF4 \\
\hline$B C-1 ; B C-10 ; B C-18 ; B C-23 ; B C-29$ & 17 & 34989583 & 35061419 & 71836 & STARD3 \\
\hline BC-28 & 17 & 31081633 & 31171045 & 89412 & MMP28 \\
\hline$B C-1 ; B C-4 ; B C-6 ; B C-9 ; B C-10 ; B C-14 ; B C 19 ; B C-26 ; B C-28$ & 17 & 59297086 & 59423954 & 126868 & $\mathrm{GH} 1 ; \mathrm{GH} 2$ \\
\hline$B C-26$ & 17 & 59067300 & 59150930 & 83630 & MAP3K3 \\
\hline
\end{tabular}

differences between primary tumor and blood were generally larger when evaluated by real time PCR compared to array CGH. Array CGH and real time PCR corresponded well with respect to chromosomal copy number alterations delineated in each sample.

\section{Discussion}

In this study, we screened for chromosomal aberrations in primary tumors and blood samples obtained from 30 patients diagnosed with breast cancer. Chromosomal abnormalities were evident, with DNA aberrations having a similar tendency to be located at specific chromosomal regions in both sample types.

Genomic DNA copy number changes occur frequently in solid tumors [16] and in association with various human cancers. Recent research has been aimed at determining the phenotype of specific copy number changes [26]. Thus, it has become important to investigate region-specific DNA copy number changes associated with tumor carcinogenesis and prognosis.

Several techniques including FISH, real time PCR, $\mathrm{LOH}$, and $\mathrm{CGH}$ have been used to detect DNA copy number changes. Array- $\mathrm{CGH}$ is a powerful technique that allows determination of DNA copy number analysis of all regions of large genomes. Unlike conventional $\mathrm{CGH}$, array $\mathrm{CGH}$ can provide better resolution and quantitative information at the level of chromosomal gain or loss. Whichever methods are used in the analysis of array $\mathrm{CGH}$ data, it is very important that the large volume of data to be validated with various methods including FISH and real time PCR [27,28]. In our study, the latter technique provided the confirmation.

The use of conventional and array CGH for DNA copy number changes in breast cancer is well established, and regions of frequent gain (1q, 8q, 11q, 16p, 17q, 19q and $20 q)$ and loss (6q, 13q, 16q, 17p and 22q) have been identified [13,29-34]. Presently, DNA copy number changes were frequently identified in both primary tumors and blood samples. A large number of regions throughout the genome were altered. DNA copy number alterations of both primary tumor and blood samples were not random. Common DNA gains were more frequently found in $1 \mathrm{q}$, $3 \mathrm{q}, 4 \mathrm{p}, 5 \mathrm{p}, 8 \mathrm{q}, 10 \mathrm{q}, 11 \mathrm{p}, 12 \mathrm{p}, 12 \mathrm{q}, 14 \mathrm{q}, 15 \mathrm{q}, 16 \mathrm{p}, 16 \mathrm{q}$, $17 p, 17 q, 19 p, 19 q, 20 q$ and $22 q$, with DNA losses detected in $6 p, 7 q, 14 q$ and $22 q$. Seven regions more frequently displayed gain in more than $50 \%$ of both the primary tumor and blood samples (Figure 1). Gain on 5 p15.33 was identified in 17 cases (57\%) of blood samples and 24 primary tumor samples $(80 \%)$. The region included four genes (AHRR, EXOC3, SLC9A3, and CEP72). AHRR encodes an aryl hydrocarbon receptor repressor, which is a bHLS/Per-ARNT-Sim transcription factor. It was recently reported that AHRR is a putative new tumor suppressor gene in multiple types of human cancers including breast cancer [35].

Other candidate genes have been described as frequently imbalanced in the genomes of the breast cancer cells (Figure 3). Gain on 8q24.3 and 20q13.33 was identified in more than $50 \%$ of the samples. Gain on $17 q 11.2$ was seen in 19 of the primary tumors $(63 \%)$ and in 17 of the blood samples (57\%). The region included the myosin XVIII A (MYO 18A) gene that is a member of the myosin superfamily, and which has been implicated in atypical myelodysplatic syndrome/proliferative disease [36]. Gain on 17q25.3, which was observed in 17 of the primary tumors (57\%) and 18 blood samples $(60 \%)$, concerns genes encoding solute carrier family 16 member 3 (SLC16A3) and casein kinase 1 delta (CSNGK1D). SLC16A3 is a hypoxia-regulated gene that is expressed in bladder and breast cell lines [37]. CSNK1D is associated with metastasis and relapse of breast cancer, and is overexpressed in lymph node positive breast cancer [38]. Gain on 22q13.33 was over represented in 15 primary tumor and 15 blood samples (50\% each). The region includes MOV10L1, PANX2, TUBGCP6, HDAC10, MAPK12, MAPK11, and 
Table 3 Summary of the most frequent aberrant regions of DNA gain and loss (Blood)

\begin{tabular}{|c|c|c|c|c|c|c|c|}
\hline Chromosome & Cytoband & $\begin{array}{l}\text { No.of patients } \\
(n=30)\end{array}$ & Frequency (\%) & Chromosome & Cytoband & $\begin{array}{l}\text { No. of patients } \\
(n=30)\end{array}$ & Frequency (\%) \\
\hline \multicolumn{8}{|c|}{ Copy number Gain } \\
\hline \multirow[t]{4}{*}{$1 p$} & $1 p 36.12$ & 13 & $13 / 30(43)$ & $12 q$ & $12 q 21.2$ & 10 & 10/30 (33) \\
\hline & $1 p 36.13$ & 12 & $12 / 30(40)$ & $14 q$ & $14 q 32.12$ & 13 & $13 / 30(43)$ \\
\hline & $1 p 36.31$ & 10 & 10/30 (33) & $15 q$ & $15 q 11.2$ & 11 & $11 / 30(37)$ \\
\hline & $1 \mathrm{p} 35.1$ & 13 & $13 / 30(43)$ & & $15 q 12$ & 10 & 10/30 (33) \\
\hline $1 q$ & $1 \mathrm{q} 23.1$ & 11 & $11 / 30(37)$ & & $15 q 25.2$ & 10 & 10/30 (33) \\
\hline \multirow[t]{2}{*}{$2 p$} & $2 \mathrm{p} 11.2$ & 11 & $11 / 30(37)$ & $16 p$ & $16 p 11.2$ & 11 & $11 / 30(37)$ \\
\hline & $2 p 13.1$ & 14 & $14 / 30(47)$ & & $16 p 13.3$ & 16 & $16 / 30(53)$ \\
\hline \multirow[t]{2}{*}{$3 p$} & $3 p 22.1$ & 10 & 10/30 (33) & $16 q$ & $16 q 22.1$ & 12 & $12 / 30(40)$ \\
\hline & $3 p 22.2$ & 11 & $11 / 30(37)$ & & $16 q 24.1$ & 13 & 13/30 (43) \\
\hline \multirow[t]{3}{*}{$3 q$} & $3 q 21.1$ & 12 & $12 / 30(40)$ & & $16 \mathrm{q} 24.3$ & 11 & $11 / 30(37)$ \\
\hline & $3 q 21.3$ & 15 & $15 / 30(50)$ & $17 p$ & $17 p 11.2$ & 13 & $13 / 30(43)$ \\
\hline & $3 q 27.1$ & 10 & 10/30 (33) & & $17 p 12$ & 11 & $11 / 30(37)$ \\
\hline $4 p$ & $4 p 16.3$ & 15 & 15/30 (50) & & 17p13.2 & 10 & 10/30 (33) \\
\hline \multirow[t]{2}{*}{$5 p$} & $5 p 13.3$ & 12 & $12 / 30(40)$ & & $17 p 13.3$ & 14 & $14 / 30(47)$ \\
\hline & $5 p 15.33$ & 17 & $17 / 30(57)$ & $17 q$ & $17 q 11.2$ & 17 & $17 / 30(57)$ \\
\hline $5 q$ & $5 q 33.1$ & 12 & $12 / 30(40)$ & & $17 q 12$ & 13 & $13 / 30(43)$ \\
\hline \multirow[t]{2}{*}{$7 q$} & $7 q 11.23$ & 12 & $12 / 30(40)$ & & $17 q 21.1$ & 10 & 10/30 (33) \\
\hline & $7 q 36.3$ & 10 & 10/30 (33) & & $17 q 21.2$ & 11 & $11 / 30(37)$ \\
\hline $8 p$ & $8 p 21.2$ & 11 & $11 / 30(37)$ & & $17 q 21.32$ & 13 & $13 / 30(43)$ \\
\hline $8 q$ & $8 q 24.3$ & 20 & $20 / 30(67)$ & & $17 q 25.3$ & 18 & $18 / 30(60)$ \\
\hline $9 p$ & $9 p 12$ & 11 & $11 / 30(37)$ & $18 q$ & $18 q 23$ & 10 & 10/30 (33) \\
\hline $9 q$ & $9 q 34.11-9 q 34.12$ & 17 & 17/30 (57) & $19 p$ & 19p13.11 & 15 & $15 / 30(50)$ \\
\hline $10 p$ & 10p15.3 & 11 & $11 / 30(37)$ & & $19 p 13.3$ & 16 & $16 / 30(53)$ \\
\hline \multirow[t]{2}{*}{$10 q$} & $10 q 22.3$ & 11 & $11 / 30(37)$ & $19 q$ & $19 q 13.2$ & 11 & $11 / 30(37)$ \\
\hline & $10 q 26.3$ & 11 & $11 / 30(37)$ & & $19 q 13.33$ & 11 & $11 / 30(37)$ \\
\hline \multirow[t]{4}{*}{$11 p$} & $11 p 11.2$ & 12 & $12 / 30(40)$ & & $19 q 13.43$ & 11 & $11 / 30(37)$ \\
\hline & $11 \mathrm{p} 15.4$ & 12 & $12 / 30(40)$ & $20 p$ & 20p12.2 & 10 & 10/30 (33) \\
\hline & $11 \mathrm{p} 15.5$ & 18 & $18 / 30(60)$ & $20 q$ & $20 q 13.12$ & 10 & 10/30 (33) \\
\hline & 11p15.5-11p15.4 & 12 & $12 / 30(40)$ & & $20 q 13.33$ & 16 & $16 / 30(53)$ \\
\hline \multirow[t]{3}{*}{$11 q$} & $11 q 12.3$ & 13 & $13 / 30(43)$ & $22 q$ & $22 q 12.2$ & 19 & 19/30 (63) \\
\hline & $11 \mathrm{q} 23.1$ & 10 & 10/30 (33) & & $22 q 13.31$ & 15 & 15/30 (50) \\
\hline & $11 \mathrm{q} 23.3$ & 11 & $11 / 30(37)$ & & $22 q 13.33$ & 15 & 15/30 (50) \\
\hline \multirow[t]{2}{*}{$12 p$} & $12 p 13.31$ & 18 & $18 / 30(60)$ & $X p$ & Xp11.22 & 14 & $14 / 30(47)$ \\
\hline & $12 \mathrm{p} 13.33$ & 12 & $12 / 30(40)$ & & Xp11.23 & 10 & $10 / 30(33)$ \\
\hline $12 q$ & $12 q 13.13$ & 10 & 10/30 (33) & $X q$ & Xq23 & 11 & $11 / 30(37)$ \\
\hline \multicolumn{8}{|c|}{ Copy number Loss } \\
\hline $1 q$ & $1 q 44$ & 5 & $5 / 30(17)$ & $11 q$ & $11 q 25$ & 6 & $6 / 30(20)$ \\
\hline $2 p$ & $2 p 25.3$ & 5 & $5 / 30(17)$ & $13 q$ & $13 q 34$ & 6 & $6 / 30(20)$ \\
\hline $2 q$ & $2 q 37.3$ & 7 & $7 / 30(23)$ & $14 q$ & $14 q 32.33$ & 8 & $8 / 30(27)$ \\
\hline $3 p$ & $3 p 26.3$ & 5 & $5 / 30(17)$ & $16 q$ & $16 q 21$ & 5 & $5 / 30(17)$ \\
\hline $5 q$ & $5 q 13.2$ & 6 & $6 / 30(20)$ & $18 p$ & $18 p 11.32$ & 8 & $8 / 30(27)$ \\
\hline $6 p$ & $6 p 25.3$ & 6 & $6 / 30(20)$ & $21 q$ & $21 q 21.1$ & 5 & $5 / 30(17)$ \\
\hline $7 q$ & $7 q 22.1$ & 6 & $6 / 30(20)$ & $22 q$ & $22 q 11.1$ & 7 & $7 / 30(23)$ \\
\hline $10 q$ & $10 q 11.22$ & 8 & $8 / 30(27)$ & & $22 q 11.21$ & 14 & $14 / 30(47)$ \\
\hline
\end{tabular}


Table 4 Summary of the most frequent aberrant regions of DNA gain and loss (Tissues)

\begin{tabular}{|c|c|c|c|c|c|c|c|}
\hline Chromosome & Cytoband & $\begin{array}{l}\text { No. of patients } \\
(n=30)\end{array}$ & Frequency (\%) & Chromosome & Cytoband & $\begin{array}{l}\text { No. of patients } \\
(n=30)\end{array}$ & Frequency (\%) \\
\hline \multicolumn{8}{|c|}{ Copy number Gain } \\
\hline $1 p$ & $1 p 36.33$ & 12 & $12 / 30(40)$ & $11 p$ & 11p15.5-11p15.4 & 13 & $13 / 30(43)$ \\
\hline \multirow[t]{5}{*}{$1 q$} & $1 \mathrm{q} 21.2$ & 12 & $12 / 30(40)$ & $12 p$ & $12 p 13.31$ & 10 & 10/30 (33) \\
\hline & $1 q 23.1$ & 14 & $14 / 30(47)$ & & $12 \mathrm{p} 13.33$ & 12 & $12 / 30(40)$ \\
\hline & $1 q 23.3$ & 12 & $12 / 30(40)$ & $12 q$ & $12 q 21.2$ & 10 & 10/30 (33) \\
\hline & $1 \mathrm{q} 24.3$ & 12 & $12 / 30(40)$ & $14 q$ & $14 q 32.12$ & 11 & $11 / 30(37)$ \\
\hline & $1 \mathrm{q} 44$ & 11 & $11 / 30(37)$ & $15 q$ & $15 q 11.2$ & 11 & $11 / 30(37)$ \\
\hline \multirow[t]{2}{*}{$2 p$} & $2 \mathrm{p} 11.1$ & 13 & $13 / 30(43)$ & & $15 q 12$ & 10 & 10/30 (33) \\
\hline & $2 p 25.1$ & 11 & $11 / 30(37)$ & & $15 q 26.3$ & 12 & $12 / 30(40)$ \\
\hline $3 q$ & $3 q 21.1$ & 12 & $12 / 30(40)$ & $16 p$ & $16 p 13.2$ & 10 & 10/30 (33) \\
\hline $4 p$ & $4 p 16.3$ & 11 & $11 / 30(37)$ & & $16 p 13.3$ & 23 & 23/30 (77) \\
\hline \multirow[t]{2}{*}{$4 q$} & $4 q 32.1$ & 10 & 10/30 (33) & $16 q$ & $16 q 22.1$ & 11 & $11 / 30(37)$ \\
\hline & $4 q 35.2$ & 10 & 10/30 (33) & $17 p$ & 17p13.3 & 10 & 10/30 (33) \\
\hline $5 p$ & $5 p 15.33$ & 24 & $24 / 30(80)$ & $17 q$ & $17 q 11.2$ & 19 & 19/30 (63) \\
\hline $7 p$ & $7 \mathrm{p} 14.1$ & 10 & 10/30 (33) & & $17 q 12$ & 11 & $11 / 30(37)$ \\
\hline \multirow[t]{5}{*}{$8 q$} & $8 q 11.1$ & 12 & $12 / 30(40)$ & & $17 q 21.1$ & 11 & $11 / 30(37)$ \\
\hline & $8 q 11.21$ & 10 & 10/30 (33) & & $17 q 25.3$ & 18 & $17 / 30(57)$ \\
\hline & $8 q 21.3$ & 13 & $13 / 30(43)$ & $18 q$ & $18 q 23$ & 15 & $15 / 30(50)$ \\
\hline & $8 q 22.2$ & 17 & $17 / 30(57)$ & $19 p$ & 19p13.3 & 13 & $13 / 30(43)$ \\
\hline & $8 q 24.3$ & 23 & $23 / 30(77)$ & $19 q$ & $19 q 13.43$ & 10 & 10/30 (33) \\
\hline $10 p$ & 10p15.3 & 10 & 10/30 (33) & $20 q$ & $20 q 13.33$ & 21 & $21 / 30(70)$ \\
\hline $10 q$ & $10 q 26.3$ & 15 & $15 / 30(50)$ & $21 q$ & $21 q 11.2$ & 11 & $11 / 30(37)$ \\
\hline \multirow[t]{2}{*}{$11 p$} & $11 p 15.4$ & 10 & 10/30 (33) & $22 q$ & $22 q 13.33$ & 15 & $15 / 30(50)$ \\
\hline & $11 p 15.5$ & 14 & $14 / 30(47)$ & $X p$ & Xp11.23 & 10 & 10/30 (33) \\
\hline \multicolumn{8}{|c|}{ Copy number Loss } \\
\hline $3 p$ & $3 p 21.31$ & 5 & $5 / 30(17)$ & $16 q$ & $16 q 23.1$ & 4 & $4 / 30(13)$ \\
\hline $4 q$ & $4 q 35.2$ & 6 & $6 / 30(20)$ & $17 p$ & 17p11.2 & 12 & $12 / 30(40)$ \\
\hline $6 p$ & $6 \mathrm{p} 25.3$ & 5 & $5 / 30(17)$ & $22 q$ & $22 q 11.1$ & 5 & $5 / 30(17)$ \\
\hline $7 q$ & $7 q 22.1$ & 6 & $6 / 30(20)$ & & $22 q 11.21$ & 11 & $11 / 30(37)$ \\
\hline $14 q$ & $14 q 32.33$ & 8 & $8 / 30(27)$ & & $22 q 11.23$ & 7 & 7/30 (23) \\
\hline $16 q$ & $16 q 22.3$ & 4 & 4/30 (13) & & & & \\
\hline
\end{tabular}

PLXNB2. Among them, histone deacetylase 10 (HDAC10), a member of class II HDACS, may play a role as a transcriptional modulator in the nucleus and is responsible for lung cancer progression and poor prognosis [39]. In addition, HDACs may also play important roles in cancer development by regulating several genes and causing abnormal gene silencing. A HDAC inhibitor is associated with growth arrest and apoptosis in breast cancer cells [40].

The strength of agreement of DNA copy numbers between primary tumor and blood was slight (Kappa = $0.138, \mathrm{p}<0.001)$. But we anticipated this result, that the copy number variant size would not be that large nor would it show specific patterns like the private tumor. We have also identified that blood mainly altered regions. Nevertheless, we have also identified the main altered regions in blood samples. 3 p22.2 is a region frequently amplified in our blood samples and this region including the MLH1 (mutL homolog 1) is known to be associated with colorectal cancer genes. Gain of 8p21.2 and 9q34.11-12 were also found in blood each about $37 \%$ and $57 \%$ out of a total of 30 samples $(11 / 30,17 / 30)$. These sites include NKX3-1 (8p21.2) and ABL1 (9q34.11-12) genes that are also known to be associated with prostate tumor suppressor gene and translocation mutation relatively in acute nonlymphocytic leukemia.

Array CGH has been successfully utilized on DNA extracted from fresh-frozen tissues, as these produce high quality nucleic acids $[17,34]$. However, sometimes fresh-frozen tissues are hard to get and store; more than $70 \%$ of the $100-200 \mathrm{mg}$ of tissue typically required needs to be comprised with tumor cells. Because the availability of fresh-frozen tissue is limited, the use of 
Table 5 Most frequently detected regions in both blood and tissue group by array CGH

\begin{tabular}{|c|c|c|c|c|}
\hline Cytoband & $\begin{array}{l}\text { Bac_position } \\
\text { (Start-End) }\end{array}$ & Gene & Blood frequency & Tissue frequency \\
\hline \multicolumn{5}{|l|}{ copy number gain } \\
\hline $1 \mathrm{q} 23.1$ & $155045002-155148010$ & SH2D2A, NTRK1, INSRR & $11 / 30(37 \%)$ & $14 / 30(47 \%)$ \\
\hline $3 q 21.1$ & $124077821-124170592$ & $D I R C 2$, SEMA5B & $12 / 30(40 \%)$ & $12 / 30(40 \%)$ \\
\hline $4 p 16.3$ & $2729092-2810076$ & SH3BP2 & $15 / 30(50 \%)$ & 10/30(33\%) \\
\hline $5 p 15.33$ & $388661-566921$ & $A H R R, E X O C 3$, SLC9A3 & $17 / 30(57 \%)$ & $24 / 30(80 \%)$ \\
\hline $5 p 15.33$ & $557250-688780$ & SLC9A3, CEP72 & $14 / 30(47 \%)$ & $24 / 30(80 \%)$ \\
\hline $8 q 24.3$ & $145649003-145759358$ & $\begin{array}{l}\text { CYHR1, KIFC2, FOXH1, PPP1R16A, GPT, } \\
\text { MFSD3, RECQL4, LRRC14, LRRC24 }\end{array}$ & 10/30(33\%) & $23 / 30(76 \%)$ \\
\hline $8 q 24.3$ & $145298570-145384455$ & & $20 / 30(67 \%)$ & $18 / 30(60 \%)$ \\
\hline $8 q 24.3$ & $145499155-145579895$ & HSF1, DGAT1, SCRT1, FBXL6, GPR172A, ADCK5 & $16 / 30(53 \%)$ & 19/30(63\%) \\
\hline 10q26.3 & $134654530-134754530$ & GPR123 & $11 / 30(37 \%)$ & $12 / 30(40 \%)$ \\
\hline $11 \mathrm{p} 15.4$ & 2812494-2941798 & $\begin{array}{l}\text { KCNQ1, KCNQ1DN, CDKN1C, SLC22A18AS, SLC22A18, } \\
\text { PHLDA2, NAP1L4 }\end{array}$ & $12 / 30(40 \%)$ & 10/30(33\%) \\
\hline $11 \mathrm{p} 15.5$ & $499204-651925$ & $\begin{array}{l}\text { HRAS, LRRC56, C11 orf35, RASSF7, IRF7, MUCDHL, SCT, } \\
\text { DRD4, DEAF1 }\end{array}$ & $18 / 30(60 \%)$ & $11 / 30(37 \%)$ \\
\hline $11 \mathrm{p} 15.5$ & 982365-1053559 & AP2A2, MUC6 & $13 / 30(43 \%)$ & $14 / 30(47 \%)$ \\
\hline $11 \mathrm{p} 15.5-11 \mathrm{p} 15.4$ & $2759787-2881783$ & KCNQ1, KCNQ1DN, CDKN1C, SLC22A18AS, SLC22A18 & $12 / 30(40 \%)$ & $13 / 30(43 \%)$ \\
\hline 12p13.31 & $6232178-6365032$ & PLEKHG6, TNFRSF1A, SCNN1A, LTBR & 18/30(60\%) & 10/30(33\%) \\
\hline $12 \mathrm{p} 13.33$ & $183679-257363$ & SLC6A12, SLC6A13 & $12 / 30(40 \%)$ & $12 / 30(40 \%)$ \\
\hline $12 q 21.2$ & $74611385-74763510$ & PHLDA1, NAP1L1 & 10/30(33\%) & 10/30(33\%) \\
\hline $14 q 32.12$ & $91451809-91569634$ & FBLN5, TRIP11, PTMAP7 & $13 / 30(43 \%)$ & $11 / 30(37 \%)$ \\
\hline $15 q 12$ & $24429411-24553848$ & GABRB3 & 10/30(33\%) & 10/30(33\%) \\
\hline $16 p 13.3$ & $979471-1055445$ & & $16 / 30(53 \%)$ & $23 / 30(76 \%)$ \\
\hline $16 p 13.3$ & 3369954-3513708 & HS3ST4, ZNF434, ZNF174, ZNF597, CLUAP1 & $12 / 30(40 \%)$ & $11 / 30(37 \%)$ \\
\hline $16 q 22.1$ & $65485602-65560334$ & CDH16, RRAD, FAM96B, CES2 & $12 / 30(40 \%)$ & $11 / 30(37 \%)$ \\
\hline 17p13.3 & $907028-1022423$ & ABR, MRPL14P1 & $14 / 30(47 \%)$ & 10/30(33\%) \\
\hline $17 q 11.2$ & $24429872-24521087$ & MYO18A & $17 / 30(57 \%)$ & 19/30(63\%) \\
\hline $17 q 21.1$ & $35466169-35565677$ & THRA, NR1D1, CASC3 & 10/30(33\%) & $11 / 30(37 \%)$ \\
\hline $17 q 25.3$ & $78432676-78562724$ & TBCD, B3GNTL1 & $11 / 30(37 \%)$ & $18 / 30(60 \%)$ \\
\hline $17 q 25.3$ & $77755881-77849251$ & SLC16A3, CSNK1D & $18 / 30(60 \%)$ & $17 / 30(57 \%)$ \\
\hline 19p13.3 & $5809230-5915258$ & FUT5, NDUFA11, CAPS, RANBP3 & $14 / 30(47 \%)$ & $13 / 30(43 \%)$ \\
\hline $19 q 13.43$ & $63514606-63629648$ & HKR2, A1BG, ZNF497, RPS5, ZNF584 & $11 / 30(37 \%)$ & 10/30(33\%) \\
\hline $20 q 13.33$ & $60334240-60438865$ & LAMA5, RPS21, CABLES2, C20orf151 & $16 / 30(53 \%)$ & 19/30(63\%) \\
\hline $22 q 13.33$ & 48930979-49068912 & $\begin{array}{l}\text { MOV10L1, PANX2, TUBGCP6, HDAC10, MAPK12, } \\
\text { MAPK11, PLXNB2 }\end{array}$ & $15 / 30(50 \%)$ & $15 / 30(50 \%)$ \\
\hline \multicolumn{5}{|l|}{ copy number loss } \\
\hline $6 p 25.3$ & 202426-307948 & DUSP22 & $6 / 30(20 \%)$ & $5 / 30(17 \%)$ \\
\hline $7 q 22.1$ & $100407386-100480418$ & MUC12, MUC17 & $6 / 30(20 \%)$ & $6 / 30(20 \%)$ \\
\hline $14 q 32.33$ & 105821330-105907464 & $\begin{array}{l}\text { IGHVIII-25-1, IGHV2-26, IGHVIII-26-1, IGHVII-26-2, } \\
\text { IGHV7-27, IGHV4-28, IGHVI-28-1, IGHV3-29, IGHV3-30, } \\
\text { IGHVII-30-1, IGHV3-30-2, IGHV4-31, IGHVII-31-1, IGHV3-32, } \\
\text { IGHV3-33, IGHVII-33-1, IGHV3-33-2, IGHV4-34, IGHV7-34-1 }\end{array}$ & $8 / 30(27 \%)$ & $8 / 30(27 \%)$ \\
\hline 22q11.1(Cross-Hybridized) & $14461738-14573360$ & DUXAP8 & $7 / 30(23 \%)$ & $5 / 30(17 \%)$ \\
\hline $22 q 11.21$ & $17158480-17233217$ & GGT2 & $14 / 30(47 \%)$ & $11 / 30(37 \%)$ \\
\hline
\end{tabular}

Bold text indicates genes associate with many different carcinoma including breast. 


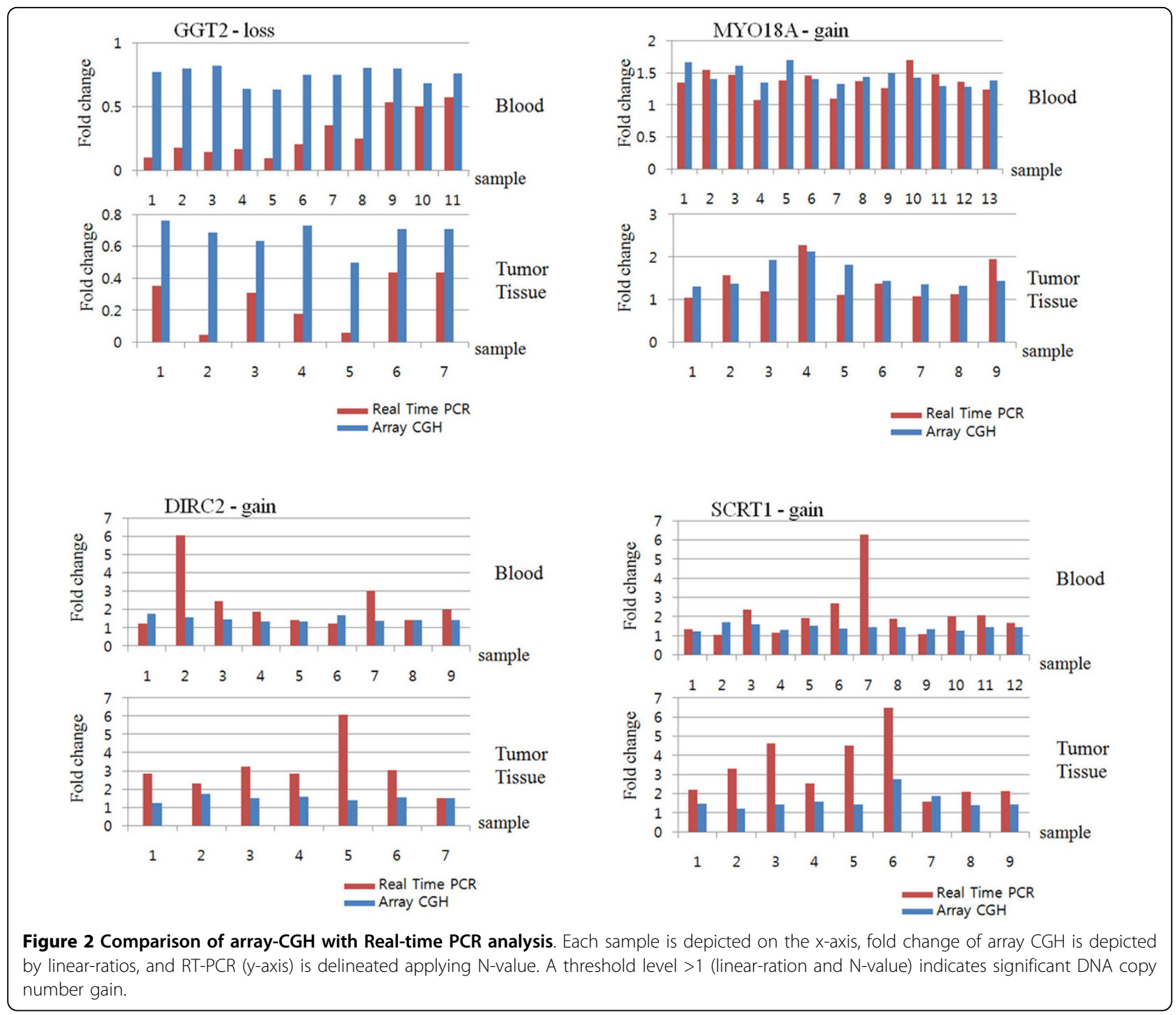

Table 6 Primers used for real time PCR analysis

\begin{tabular}{cllcc}
\hline Gene & \multicolumn{1}{c}{ Forward sequence } & \multicolumn{1}{c}{ Reverse sequence } & Region & CNV status \\
\hline DIRC2 & CAGGCAATGGTGAGATCCTG & CCCGAAACAGGAGGAGAAG & $3 q 21.1$ & gain \\
SCRT1 & GTGGGGAGAGGATCAGGAA & CCAGGCTTCAGGGAAGAGAC & 8q24.3 & gain \\
MYO18A & GATATCCCCTTGGGCCTGTA & CAGAATGGTATGCCTCTGG & $17 \mathrm{q} 11.2$ & gain \\
GGT2 & TGGTAGCTTATCCTGGGCCT & ATGGGAGAAGACAGGGATGC & $22 \mathrm{q} 11.21$ & loss \\
\hline
\end{tabular}

006 March: UCSC genome browser.

FFPE tissue has been explored [19,41]. To date, however, the use of FFPE tissues has been hampered by increased degradation, reduction in the yield of total genomic DNA, and decrease in reliability of DNA $[18,42,43]$.

The results demonstrate the utility of array CGH for detecting DNA copy number changes from primary tumors and peripheral blood, therefore showing the potential use of blood samples in cancer patients in the absence of fresh-frozen tissue. There was a slight agreement of DNA copy number alterations between primary tumor and blood in breast cancer patients. Therefore, further research is necessary for a definitive confirmation of the use of the peripheral blood as a support for primary tumors in identifying putative breast cancer genes through investigation of DNA copy number alterations in a large number of primary tumor and blood samples. 


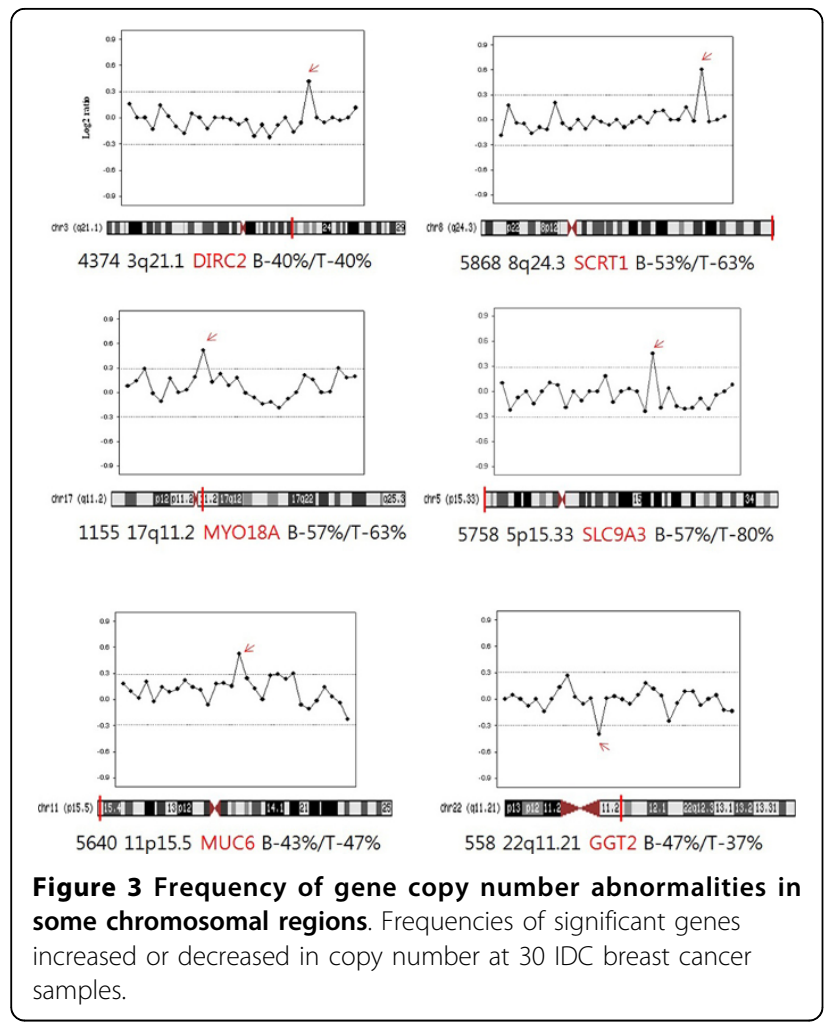

\section{Acknowledgements}

This study was supported by a grant from the Korean Health 21 R\&D Project, Ministry of Health Welfare, Republic of Korea (01-PJ3-PG6-01GN07-0004).

\section{Author details}

'Department of Surgery, The Catholic University, Seoul, Korea. ${ }^{2}$ Catholic Neuroscience Center, The Catholic University, Seoul, Korea. ${ }^{3}$ Department of Occupational and Environmental Medicine, St. Mary's Hospital, The Catholic University, Seoul, Korea.

\section{Authors' contributions}

JSB drafted the manuscript and contributed to conception and design. CJS contributed to acquisition and analysis of data. WCP, BJS, JSK and YL participated in the design of the study and revised ir critically for important intellectual content. SHB participated in the design of study and performed the statistical analysis. SSJ conceived of the study and pariticipated in its design and coordination. All authors read and approved the final manuscript

\section{Competing interests}

The authors declare that they have no competing interests.

Received: 26 December 2009 Accepted: 21 April 2010 Published: 21 April 2010

\section{References}

1. Choi Y, Kim YJ, Shin HR, Noh DY, Yoo KY: Long-term prediction of female breast cancer mortality in Korea. Asian Pac J Cancer Prev 2005, 6:16-21.

2. Cleator S, Ashworth A: Molecular profiling of breast cancer: clinical implications. Br J Cancer 2004, 90:1120-1124.

3. Cowell JK, LaDuca J, Rossi MR, Burkhardt T, Nowak NJ, Matsui S: Molecular characterization of the $t(3 ; 9)$ associated with immortalization in the MCF10A cell line. Cancer Genet Cytogenet 2005, 163:23-29.
4. Morabito A, Magnani E, Gion M, Sarmiento R, Capaccetti B, Longo R, Gattuso D, Gasparini G: Prognostic and predictive indicators in operable breast cancer. Clin Breast Cancer 2003, 3:381-390.

5. Sorlie T, Perou CM, Tibshirani R, Aas T, Geisler S, Johnsen H, Hastie T, Eisen MB, Rijn van de M, Jeffrey SS, Thorsen T, Quist H, Matese JC, Brown PO, Botstein D, Eystein Lønning P, Børresen-Dale AL: Gene expression patterns of breast carcinomas distinguish tumor subclasses with clinical implications. Proc Natl Acad Sci USA 2001, 98:10869-10874.

6. van 't Veer LJ, Dai H, Vijver van de MJ, He YD, Hart AA, Mao M, Peterse HL, Kooy van der K, Marton MJ, Witteveen AT, Schreiber GJ, Kerkhoven RM, Roberts C, Linsley PS, Bernards R, Friend SH: Gene expression profiling predicts clinical outcome of breast cancer. Nature 2002, 415:530-536.

7. Lengauer C, Kinzler KW, Vogelstein B: Genetic instabilities in human cancers. Nature 1998, 396:643-649.

8. Weber BL: Cancer genomics. Cancer Cell 2002, 1:37-47.

9. Callagy G, Pharoah P, Chin SF, Sangan T, Daigo Y, Jackson L, Caldas C: Identification and validation of prognostic markers in breast cancer with the complementary use of array-CGH and tissue microarrays. J Pathol 2005, 205:388-396.

10. Garnis C, Lockwood WW, Vucic E, Ge Y, Girard L, Minna JD, Gazdar AF, Lam S, MacAulay C, Lam WL: High resolution analysis of non-small cell lung cancer cell lines by whole genome tiling path array CGH. Int J Cancer 2006, 118:1556-1564.

11. Weiss MM, Kuipers EJ, Postma C, Snijders AM, Pinkel D, Meuwissen SG, Albertson D, Meijer GA: Genomic alterations in primary gastric adenocarcinomas correlate with clinicopathological characteristics and survival. Cell Oncol 2004, 26:307-317.

12. Wolf M, Mousses $S$, Hautaniemi $S$, Karhu R, Huusko P, Allinen M, Elkahloun A, Monni O, Chen Y, Kallioniemi A, Kallioniemi OP: Highresolution analysis of gene copy number alterations in human prostate cancer using CGH on CDNA microarrays: impact of copy number on gene expression. Neoplasia 2004, 6:240-247.

13. Pinkel D, Segraves R, Sudar D, Clark S, Poole I, Kowbel D, Collins C, Kuo WL, Chen C, Zhai Y, Dairkee SH, Ljung BM, Gray JW, Albertson DG: High resolution analysis of DNA copy number variation using comparative genomic hybridization to microarrays. Nature Genetics 1998, 20:207-211.

14. Snijders AM, Nowak N, Segraves R, Blackwood S, Brown N, Conroy J, Hamilton G, Hindle AK, Huey B, Kimura K, Law S, Myambo K, Palmer J, Ylstra B, Yue JP, Gray JW, Jain AN, Pinkel D, Albertson DG: Assembly of microarrays for genome-wide measurement of DNA copy number. Nat Genet 2001, 29:263-264.

15. Solinas-Toldo S, Lampel S, Stilgenbauer S, Nickolenko J, Benner A, Dohner $\mathrm{H}$, Cremer T, Lichter P: Matrix-based comparative genomic hybridization: biochips to screen for genomic imbalances. Genes Chromosomes Cancer 1997, 20:399-407.

16. Albertson DG, Collins C, McCormick F, Gray JW: Chromosome aberrations in solid tumors. Nat Genet 2003, 34:369-376.

17. Loo LW, Grove DI, Williams EM, Neal CL, Cousens LA, Schubert EL, Holcomb IN, Massa HF, Glogovac J, Li Cl, Malone KE, Daling JR, Delrow JJ, Trask BJ, Hsu L, Porter PL: Array comparative genomic hybridization analysis of genomic alterations in breast cancer subtypes. Cancer Res 2004, 64:8541-8549.

18. MC Sherry EA, Goldrick AM, Kay EW, Hopkins AM, Gallagher WM, Dervan PA: Formalin-fixed paraffin-embedded clinical tissues show spurious copy number changes in array-CGH profiles. Clinical genetics 2007, 72:441-447.

19. van Beers EH, Joosse SA, Ligtenberg MJ, Fles R, Hogervorst FB, Verhoef $S$, Nederlof PM: A multiplex PCR predictor for aCGH success of FFPE samples. Br J Cancer 2006, 94:333-337.

20. Stankiewicz P, Beaudet AL: Use of array CGH in the evaluation of dysmorphology, malformations, developmental delay, and idiopathic mental retardation. Current opinion in genetics 2007, 17:182-192.

21. Morgan BL, Chao CR: The effects of hypoxia on growth cones in the ovine fetal brain. J Matern Fetal Neonatal Med 2004, 16:55-59.

22. Williams TD, Gensberg K, Minchin SD, Chipman JK: A DNA expression array to detect toxic stress response in European flounder (Platichthys flesus). Aquat Toxicol 2003, 65:141-157. 
23. Escot C, Theillet C, Lidereau R, Spyratos F, Champeme MH, Gest J, Callahan R: Genetic alteration of the c-myc protooncogene (MYC) in human primary breast carcinomas. Proc Natl Acad Sci USA 1986, 83:4834-4838.

24. Visscher DW, Wallis T, Awussah S, Mohamed A, Crissman JD: Evaluation of MYC and chromosome 8 copy number in breast carcinoma by interphase cytogenetics. Genes Chromosomes Cancer 1997, 18:1-7.

25. Varley JM, Swallow JE, Brammar WJ, Whittaker JL, Walker RA: Alterations to either c-erbB-2(neu) or c-myc proto-oncogenes in breast carcinomas correlate with poor short-term prognosis. Oncogene 1987, 1:423-430.

26. Fridlyand J, Snijders AM, Ylstra B, Li H, Olshen A, Segraves R, Dairkee S, Tokuyasu T, Ljung BM, Jain AN, McLennan J, Ziegler J, Chin K, Devries S, Feiler H, Gray JW, Waldman F, Pinkel D, Albertson DG: Breast tumor copy number aberration phenotypes and genomic instability. BMC Cancer 2006, 6:96.

27. Ginzinger DG: Gene quantification using real-time quantitative PCR: an emerging technology hits the mainstream. Experimental hematology 2002, 30:503-512.

28. Hackett CS, Hodgson JG, Law ME, Fridlyand J, Osoegawa K, de Jong PJ, Nowak NJ, Pinkel D, Albertson DG, Jain A, Jenkins R, Gray JW, Weiss WA Genome-wide array $\mathrm{CGH}$ analysis of murine neuroblastoma reveals distinct genomic aberrations which parallel those in human tumors. Cancer research 2003, 63:5266-5273.

29. Albertson DG: Profiling breast cancer by array CGH. Breast Cancer Res Treat 2003, 78:289-298.

30. Nishizaki T, Chew K, Chu L, Isola J, Kallioniemi A, Weidner N, Waldman FM: Genetic alterations in lobular breast cancer by comparative genomic hybridization. Int J Cancer 1997, 74:513-517.

31. Persson K, Pandis N, Mertens F, Borg A, Baldetorp B, Killander D, Isola J: Chromosomal aberrations in breast cancer: a comparison between cytogenetics and comparative genomic hybridization. Genes, chromosomes 1999, 25:115-122.

32. Pollack JR, Perou CM, Alizadeh AA, Eisen MB, Pergamenschikov A, Williams CF, Jeffrey SS, Botstein D, Brown PO: Genome-wide analysis of DNA copy-number changes using cDNA microarrays. Nature Genetics 1999, 23:41-46.

33. Rennstam K, Ahlstedt-Soini M, Baldetorp B, Bendahl PO, Borg A, Karhu R, Tanner M, Tirkkonen M, Isola J: Patterns of chromosomal imbalances defines subgroups of breast cancer with distinct clinical features and prognosis. A study of 305 tumors by comparative genomic hybridization. Cancer Res 2003, 63:8861-8868.

34. Tirkkonen M, Tanner M, Karhu R, Kallioniemi A, Isola J, Kallioniemi OP: Molecular cytogenetics of primary breast cancer by CGH. Genes Chromosomes Cancer 1998, 21:177-184.

35. Zudaire E, Cuesta N, Murty V, Woodson K, Adams L, Gonzalez N, Martnez A, Narayan G, Kirsch I, Franklin W, Hirsch F, Birrer M, Cuttitta F: The aryl hydrocarbon receptor repressor is a putative tumor suppressor gene in multiple human cancers. Journal of Clinical Investigation 2008, 118:640-650.

36. Walz C, Chase A, Schoch C, Weisser A, Schlegel F, Hochhaus A, Fuchs R, Schmitt-Graff A, Hehlmann R, Cross NC, Reiter A: The $t(8 ; 17)(p 11 ; q 23)$ in the $8 p 11$ myeloproliferative syndrome fuses MYO18A to FGFR1. Leukemia 2005, 19:1005-1009.

37. Ord JJ, Streeter EH, Roberts IS, Cranston D, Harris AL: Comparison of hypoxia transcriptome in vitro with in vivo gene expression in human bladder cancer. Br J Cancer 2005, 93:346-354.

38. Abba MC, Sun H, Hawkins KA, Drake JA, Hu Y, Nunez Ml, Gaddis S, Shi T, Horvath S, Sahin A, Aldaz CM: Breast cancer molecular signatures as determined by SAGE: correlation with lymph node status. Mol Cancer Res 2007, 5:881-890

39. Osada H, Tatematsu Y, Saito H, Yatabe Y, Mitsudomi T, Takahashi T: Reduced expression of class II histone deacetylase genes is associated with poor prognosis in lung cancer patients. International journal of cancer 2004, 112:26-32.

40. Fuino L, Bali P, Wittmann S, Donapaty S, Guo F, Yamaguchi H, Wang HG, Atadja P, Bhalla K: Histone deacetylase inhibitor LAQ824 down-regulates Her-2 and sensitizes human breast cancer cells to trastuzumab, taxotere, gemcitabine, and epothilone B. Mol Cancer Ther 2003, 2:971-984.

41. Devries S, Nyante S, Korkola J, Segraves R, Nakao K, Moore D, Bae H, Wilhelm M, Hwang S, Waldman F: Array-based comparative genomic hybridization from formalin-fixed, paraffin-embedded breast tumors. J Mol Diagn 2005, 7:65-71.
42. Little SE, Vuononvirta R, Reis-Filho JS, Natrajan R, Iravani M, Fenwick K, Mackay A, Ashworth A, Pritchard-Jones K, Jones C: Array CGH using whole genome amplification of fresh-frozen and formalin-fixed, paraffinembedded tumor DNA. Genomics 2006, 87:298-306.

43. Serth J, Kuczyk MA, Paeslack U, Lichtinghagen R, Jonas U: Quantitation of DNA extracted after micropreparation of cells from frozen and formalinfixed tissue sections. Am J Pathol 2000, 156:1189-1196.

doi:10.1186/1477-7819-8-32

Cite this article as: Bae et al:: Genomic alterations of primary tumor and blood in invasive ductal carcinoma of breast. World Journal of Surgical Oncology 2010 8:32.

\section{Submit your next manuscript to BioMed Central and take full advantage of:}

- Convenient online submission

- Thorough peer review

- No space constraints or color figure charges

- Immediate publication on acceptance

- Inclusion in PubMed, CAS, Scopus and Google Scholar

- Research which is freely available for redistribution
Ciomed Central 